\title{
Transgenic Suppression of Cell Death Limits Penetration Success of the Soybean Rust Fungus Phakopsora pachyrhizi into Epidermal Cells of Barley
}

\author{
Caroline Hoefle, Marco Loehrer, Ulrich Schaffrath, Markus Frank, Holger Schultheiss, and Ralph Hückelhoven
}

First and sixth authors: Lehrstuhl für Phytopathologie, Technische Universität München, 85350 Freising-Weihenstephan, Germany; second and third authors: Institute for Biology III (Plant Physiology), RWTH Aachen, D-52056 Aachen, Germany; and fourth and fifth authors: BASF Plant Science GmbH, Agricultural Center, 67117 Limburgerhof, Germany. C. Hoefle and M. Loehrer contributed equally to this study. Accepted for publication 10 November 2008.

\begin{abstract}
Hoefle, C., Loehrer, M., Schaffrath, U., Frank, M., Schultheiss, H., and Hückelhoven, R. 2009. Transgenic suppression of cell death limits penetration success of the soybean rust fungus Phakopsora pachyrhizi into epidermal cells of barley. Phytopathology 99:220-226.

The basidiomycete Phakopsora pachyrhizi (P. pachyrhizi) causes Asian soybean rust, one of the most devastating plant diseases on soybean. When inoculated on the nonhost barley $P$. pachyrhizi caused only very small necrotic spots, typical for an incompatible interaction, which involves a hypersensitive cell death reaction. A microscopic inspection of the interaction of barley with $P$. pachyrhizi revealed that the fungus germinated on barley and formed functional appressoria on epidermal cells. The fungus attempted to directly penetrate through periclinal cell walls but often failed, arrested in plant cell wall appositions that stained
\end{abstract}

ABSTRACT positively for callose. Penetration resistance depends on intact ROR1 (REQUIRED FOR mlo-SPECIFIED RESISTANCE 1) and ROR2 genes of barley. If the fungus succeeded in penetration, epidermal cell death took place. Dead epidermal cells did not generally restrict fungal development but allowed for mesophyll invasion, which was followed by mesophyll cell death and fungal arrest. Transient or stable over expression of the barley cell death suppressor BAX inhibitor-1 reduced both epidermal cell death and fungal penetration success. Data suggest that $P$. pachyrhizi provokes a programmed cell death facilitating fungal entry into epidermal cells of barley.

Additional keywords: hypersensitive reaction, nonhost resistance, transient transformation.
The basidiomycete fungus Phakopsora pachyrhizi, the causal agent of Asian soybean rust, has the potential to cause severe crop losses. Soybean plants infected with $P$. pachyrhizi can be completely defoliated within 2 weeks. Originally found in Japan, the fungus has spread worldwide and can now be detected in nearly all areas in which soybean is grown (50). In the genus Phakopsora the two species P. meibomiae and P. pachyrhizi infect soybean. $P$. pachyrhizi is the more aggressive pathogen on soybean although both species are closely related with $80 \%$ similarity in their internal transcribed spacer (ITS) rRNA sequences (16).

P. pachyrhizi has a broad host range comprising more than 150 species in at least 25 genera (51). The occurrence of uredo-, telio-, and very rarely basidiospores were reported from the hemicyclic $P$. pachyrhizi. The uredospores are the most important and numerous spores for the progression and the spread of the disease (60).

After host contact, uredospores quickly germinate leading to the development of a round shaped appressorium nearly the same size as the spore. The penetration hypha produced from the appressorium directly penetrates the epidermis of the host plant $(32,33)$. This is unusual as most rust fungi form appressoria on

Corresponding author: R. Hückelhoven; E-mail address: hueckelhoven@wzw.tum.de

* The $e$-Xtra logo stands for "electronic extra" and indicates that Figures 1 and 3 appear in color online.

doi:10.1094/PHYTO-99-3-0220

This article is in the public domain and not copyrightable. It may be freely reprinted with customary crediting of the source. The American Phytopathological Society, 2009. stomata and invade the plant by penetrating into substomatal cavities. Penetrated epidermal cells mostly become necrotic and the fungus invades the mesophyll. The role of epidermal cell death for resistance or pathogenesis is not known. After leaving the epidermal cell, $P$. pachyrhizi forms the first septum and hyphae grow in the intercellular space of the mesophyll. After development of haustorial mother cells the fungus forms haustoria in mesophyll cells (32). Eleven to twelve days after inoculation, newly developed uredospores complete the asexual infection cycle (32).

P. pachyrhizi germinates and develops appressoria on nonhost plants such as Arabidopsis and potato but no sporulation occurs, although the fungus is sometimes successful in penetrating the nonhost plant $(23,38)$. It is assumed that similar defense reactions are active in host and nonhost resistance, but the defense reaction is faster and more pronounced in nonhost interactions. Apparently, a pathogen has to suppress plant defense to be successful on a given plant $(7,25,53)$. For some rust fungi, a stomata lip or a similar surface topography is necessary for induction of appressoria development $(22,44)$. This seems not to be the case for $P$. pachyrhizi that directly penetrates epidermal cells through the periclinal cell wall. During penetration, $P$. pachyrhizi is presumably recognized by the plant by releasing general elicitors also referred to as pathogen-associated molecular patterns (PAMPs) or plant endogenous elicitors inducing defense reactions $(7,25,30,53)$. A typical resistance reaction in host and nonhost resistance to directly penetrating fungi is the formation of cell wall appositions (CWAs, synonym: papillae) at the site of pathogen attack $(25,46,61)$. Although the significance of CWAs in penetration resistance is still a matter of debate, there are reports of effective penetration defense. For instance, the mlo-resistance 
to Blumeria graminis f. sp. hordei in barley and the successful defense in the interaction between Arabidopsis and nonadapted $B$. graminis $\mathrm{f}$. $\mathrm{sp}$. hordei or Colletotrichum $\mathrm{sp}$. involves the formation of nonpenetrated CWAs $(12,17,48)$. The chemical composition of CWAs and the pace of formation and compaction might be crucial for successful penetration resistance $(2,25,55)$. Barley basal or mlo-mediated penetration resistance to $B$. graminis builds on intact REQUIRED FOR mlo-SPECIFIED RESISTANCE 1 (RORI) and ROR2 genes $(12,17,43,54)$.

Once the pathogen has penetrated the cell, the hypersensitive reaction (HR) including a form of programmed cell death (PCD), becomes important especially in defense against biotrophic pathogens. Originally the HR was described as rapid and localized cell death induced by rust fungi in resistant cereals as reviewed by Heath (20). Further investigations revealed the HR as a common defense mechanism in plants $(20,39)$. The HR is a programmed process dependent on an active metabolism of the attacked cell $(19,20)$ and is preceded in many interactions by an increase of cytosolic $\mathrm{Ca}^{2+}$, generation of reactive oxygen species (ROS) and nitric oxide $(20,39,57)$. The HR shares many features with apoptosis, which is a mechanism of PCD conserved in metazoans to eliminate superfluous or harmful cells $(5,34,40)$. The animal pro-apoptotic regulator BAX induces $\mathrm{PCD}$ by the release of cytochrome $\mathrm{c}$ from the mitochondria triggering a proteolytic caspase cascade and finally cell death (18). Expression of BAX also induces cell death in plants $(4,14,37)$, indicating conserved mechanisms of PCD induction in animals and plants. Although no plant homolog of BAX has been found, the BAX antagonistic protein BAX Inhibitor-1 (BI-1) is conserved, perhaps with homologs in all eukaryotes (58). Besides its cell death modulating function, BI-1 influences the defense reaction of plants to pathogens and abiotic stress (24).

Expression of BI-1 in Arabidopsis is responsive to abiotic and biotic stress such as pathogen attack (45). Pathogen induced BI-1 expression was also found in barley and tomato $(26,27,59)$. In rice suspension-cultured cells, BI-1 expression was down regulated after treatment with a cell death initiating elicitor derived from Magnaporthe oryzae (41). Arabidopsis atbi-1 knockout mutants exhibit an accelerated progression of cell death after treatment with fungal toxin and an increased sensitivity to heat shock induced cell death (56). Transient over expression of barley BI-1 in barley epidermal cells provoked susceptibility to the nonadapted wheat powdery mildew fungus $B$. graminis $\mathrm{f}$. sp. tritici and leads to breakdown of mlo-mediated penetration resistance against $B$. graminis f. sp. hordei $(15,26)$. Over expression of BI-1 also weakened BAX-induced cell death in barley and transiently supported haustorium formation in race-specifically resistant MLA12-barley, suggesting a delay of epidermal HR (14). In contrast, over expression of barley BI-1 in carrots confers resistance to fungus-induced leaf necrosis caused by the necrotrophic pathogen Botrytis cinerea (28).

Nonhost resistance of plants to nonadapted microbial pathogens is considered durable and might be suitable to identify effective resistance mechanism to fungal pathogens. We microscopically investigated the nonhost interaction of different barley $R O R$ genotypes and $P$. pachyrhizi and took advantage of the cell death inhibiting function of BI-1 to analyze a potential link of cell death and penetration resistance. Astonishingly, BI-1 over expression did not lead to suppression of defense but resulted in enhanced development of nonpenetrated CWAs in the attacked barley cells and a concomitant enhanced penetration resistance to $P$. pachyrhizi. This suggests that cell survival is crucial for preventing $P$. pachyrhizi from epidermis penetration.

\section{MATERIALS AND METHODS}

Plants, pathogens, and inoculation. Barley (Hordeum vulgare L.) plants were grown in the green house at $18^{\circ} \mathrm{C}$ with relative humidity of 50 to $60 \%$ and a $12 \mathrm{~h} / 12 \mathrm{~h}$ light and dark cycle. Proliferation of a Brazilian isolate from the Asian soybean rust fungus $P$. pachyrhizi (BASF AG, Agrarzentrum Limburgerhof, Germany) was performed on soybean plants (Glycine max cv. Oxford) in the green house at $25^{\circ} \mathrm{C}$ with $65 \%$ relative humidity and a photoperiod of $12 \mathrm{~h} / 12 \mathrm{~h}$ light and dark cycle. After inoculation, plants were transferred for $24 \mathrm{~h}$ to a dark chamber with $100 \%$ humidity.

Transient transformation assay. Transient transformation of barley leaf segments was performed as described by (47). Barley cv. Hanna was used for the transient transformation experiments. Each shot was composed of $100 \mu \mathrm{g}$ of $0.6-\mu \mathrm{m}$ gold particles coated with $1.6 \mu \mathrm{g}$ of the reporter plasmid pGFP (with the GFP gene transcribed from a CaMV35S promoter) and $1.6 \mu \mathrm{g}$ of the empty vector pGY-1 or the pBI-1 over expression construct (26). The Biolistic Particle Delivery System PDS-1000/He System (Bio-Rad, München) was used for ballistic transformation of barley leaf segments. The leaves were bombarded $24 \mathrm{~h}$ before inoculation and analyzed $18 \mathrm{~h}$ postinoculation (hpi) with $P$. pachyrhizi by fluorescence microscopy. Inoculation density was 100 spores $/ \mathrm{mm}^{2}$. GFP expressing cells were identified by blue light excitation. As $P$. pachyrhizi developed no haustoria in the epidermal cells, interaction sites of $P$. pachyrhizi with transformed cells were distinguished in penetrated and nonpenetrated cells. Cells penetrated by more than one penetration hypha or attacked by several appressoria were counted only once. Interactions with stomata and stomata guard cells were excluded from the analysis. To visualize fungal structures leaves were stained $30 \mathrm{~s}$ in $0.3 \%$ Calcofluor ([wt/vol], Sigma-Aldrich, Steinheim, Germany). Penetration efficiency was calculated by division of counted interaction sites by the number of penetrated cells and multiplied by 100. The percentage of penetration efficiency in comparison to the control experiment was taken as measure of plant resistance at the single cell level.

Cytological analysis. For microscopic analysis primary leave segments of barley were fixed on $1 \% \mathrm{H}_{2} \mathrm{O}$-agar 7 days after germination and sprayed with a spore suspension of $P$. pachyrhizi. The inoculation density for microscopic analysis was 20 spores/ $\mathrm{mm}^{2}$. The transgenic barley plants analyzed in this work have as background the barley cv. Golden Promise. Inoculated leaves of transgenic barley plants and controls were stained with combined Uvitex/Aniline blue-staining. The leaves were decolorized in a chloroform/methanol solution $(2: 1[\mathrm{vol} / \mathrm{vol}])$ and boiled afterwards $1.5 \mathrm{~min}$ in a lactophenol/ethanol solution $(2: 1$ [ $\mathrm{vol} / \mathrm{vol}])$. Leaves were left in the lactophenol/ethanol solution at room temperature over night and washed the next day sequentially with $50 \%$ ethanol, $0.05 \mathrm{M}$ sodium hydroxide, water and finally with $0.1 \mathrm{M}$ Tris- $\mathrm{HCl}$ (pH 8.5). Subsequently, leaves were incubated $5 \mathrm{~min}$ in Uvitex solution $(0.1 \%$ Uvitex $2 \mathrm{~B}$, Polysciences Inc., Warrington, $\mathrm{PA}$, in $0.1 \mathrm{M}$ Tris- $\mathrm{HCl}, \mathrm{pH}$ 8.5) to stain fungal structures. To prepare the leaves for the aniline blue staining they were washed with water and $0.1 \mathrm{M}$ potassium phosphate buffer $(\mathrm{pH}$ 9.2). For aniline blue staining leaves were incubated in the aniline blue staining solution $(0.05 \mathrm{M}$ aniline blue in $0.067 \mathrm{M}$ potassium phosphate buffer, $\mathrm{pH}$ 9.2) over night and analyzed the next day.

Barley cv. Hanna and soybean cv. Oxford were used for the evaluation of $P$. pachyrhizi development. Primary leaves of soybean and barley were stained and analyzed $0,6,10,14,24$, and $48 \mathrm{hpi}$. For Coomassie staining, leaves were decolorized in a ethanol/acetic acid solution (6:1 [ $\mathrm{vol} / \mathrm{vol}])$ over night and submerged $5 \mathrm{~min}$ in Coomassie staining solution $(0.3 \%$ Coomassie Brilliant Blue R250 [wt/vol] Bio-Rad, Hercules CA, 7.5\% trichloroacetic acid [wt/vol], 30\% methanol [vol/vol]). Afterwards leaves were washed with water and analyzed by microscopy. For staining of fungal structures by wheat germ agglutinin Alexa Fluor 488 (WGA, Molecular Probes, Eugene, OR) barley leaves were first incubated $40 \mathrm{~min}$ in $10 \%$ potassium hydrochloride 
(wt/vl). Pretreated leaves were washed 5 times with PBS-buffer $\left(137 \mathrm{mM} \mathrm{NaCl}, 10 \mathrm{mM} \mathrm{Na} \mathrm{HPO}_{4} \times 7 \mathrm{H}_{2} \mathrm{O}, 1.76 \mathrm{mM} \mathrm{KH} \mathrm{KO}_{4}\right.$, $2.69 \mathrm{mM} \mathrm{KCl}, \mathrm{pH}$ 7.4) and infiltrated with the WGA-Alexa Fluor 488 solution $(1 \mu \mathrm{g} / \mathrm{ml}$ in $1 \times$ phosphate-buffered saline [PBS] $)$ for $10 \mathrm{~min}$ at $100 \mathrm{mbar}$ pressure. Stained leaves were immediately analyzed or stored in the staining solution at $4^{\circ} \mathrm{C}$ in the dark.

Mutant barley ( $H$. vulgare) plants used in this study were derived from a cross between the mutant line M100 (Mlo Rorl rarl-2) in the genetic background of cv. Sultan5 (49) and the mutant line A89 (Mlo rorl-1 Rarl) which has a cv. Ingrid genetic background (17) as described by (10). Plants carrying mutations in ROR2 were derived from the mutagenesis of BCIngridmlo5 and designated as line A44 (mlo5 Rarl ror2-1) (17). For microscopic analysis of mutant barley plants, uredospores were suspended in a solution of $0.1 \%(\mathrm{vol} / \mathrm{vol})$ Tween-20 in distilled water at a final concentration of $1 \mathrm{mg} / \mathrm{ml}$. Primary leaves of 7-day-old barley plants were spray-inoculated and incubated in a dark moist chamber at $26^{\circ} \mathrm{C}$ and $100 \%$ relative humidity. After $24 \mathrm{~h}$, plants were brought back to the growth chamber and were kept under the same temperature and light conditions as described previously.

For the analysis of barley mutants inoculated plants were harvested at the time-points indicated and stained with trypan blue according to a modified protocol (31). Therefore leaves were submerged in ethanolic lactophenol-trypan blue staining solution and heated to $68^{\circ} \mathrm{C}$ for $45 \mathrm{~min}$. Subsequently, the staining solution was replaced by a saturated chloral hydrate solution $(2.5 \mathrm{~g} / \mathrm{ml})$ which was changed several times until the leaves were cleared. Leaves were stored in $50 \%$ (vol/vol) glycerol. Fungal infection sites were inspected by bright field microscopy using a Leica DMRBE microscope (Leica, Germany). From each genotype a total of four leaves were analyzed and 50 to 160 infection sites were inspected per leaf and time point.

\section{RESULTS}

Development of $\boldsymbol{P}$. pachyrhizi on soybean and barley. To study the development of $P$. pachyrhizi on host plant soybean and the nonhost barley, we inoculated the plants with uredospores of $P$. pachyrhizi and inspected them macro- and microscopically. Inoculation of barley with $P$. pachyrhizi led to the development of necrotic lesions on the leaves 9 days postinoculation (dpi). On soybean chlorotic regions occurred around the developing uredia and spread rapidly over the entire leaf. However, on barley leaves lesions did not spread over a size of approximately $2 \mathrm{~mm}^{2}$, and no sporulation took place. On soybean, the fungus produced the first visible uredospores $9 \mathrm{dpi}$ on the abaxial sides of the leaves.

To follow the first steps of fungal development on barley and soybean plants, we inoculated $P$. pachyrhizi on leaf samples for microscopic inspection after different time intervals. On soybean, formation of appressoria took place $6 \mathrm{hpi}$. The first epidermal cells penetrated by the fungus were observed 10 hpi followed by growth of the fungus into the intercellular space of the mesophyll 24 hpi.

Progression of $P$. pachyrhizi was a little delayed on the nonhost barley. It took $10 \mathrm{hpi}$ before most of the spores had formed appressoria (Fig. 1A). At the sites where P. pachyrhizi succeeded in penetration, epidermal cells usually died and showed bright blue whole cell fluorescence after staining with aniline blue for callose (Fig. 1B). First epidermal cell death after penetration of the fungus became apparent 14 hpi followed by some hyphal growth in the mesophyll (Fig. 1B and C). Subsequently, the fungus was arrested accompanied by collapse of a few mesophyll cells $48 \mathrm{hpi}$. Although the fungus was successful in penetration of epidermal cells and showed some growth in the mesophyll, we never observed haustoria in barley suggesting that mesophyll cells died during or shortly after fungal penetration. However, $P$. pachyrhizi also often failed to penetrate epidermal cells of barley, which then displayed callosic CWAs at sites of penetration attempts (Fig. 1D). Nonpenetrated cells with visible CWAs survived fungal attack. Hence, the fungus seemed to require epidermis cell death for successful penetration or penetration led to cell death.

Penetration resistance of barley ror genotypes. Because $P$. pachyrhizi attempts to directly penetrate barley epidermal cells, we tested whether ror 1 or ror 2 genotypes would differ in penetration resistance from wild type. We compared $M L O$ RORI $R O R 2$ wild type (cv. Ingrid) with $M L O$ rorl ROR2, mlo5 ROR1 ROR2 (Ingrid near isogenic backcross mlo5) with mlo5 rorl ROR 2 and mlo5 ROR1 ROR2 with mlo5 ROR1 ror 2 at 2 or 4 days after inoculation. Microscopic evaluation of fungal appressoria on barley cells and corresponding tryphan blue staining of attacked cells or subjacent mesophyll cells revealed significant impacts of both ror 1 and ror 2 mutations on fungal penetration success. ROR1 ROR2 wild type genotypes stopped fungal penetration attempts in about $40 \%$ of all interaction sites (Fig. 2). However, both ror 1 or ror 2 genotypes displayed less interactions, where the fungus was already stopped in the appressorial stage in CWAs, and more tryphan blue staining in the epidermis and the mesophyll indicative of cell death and of fungal progression (Fig. 2). In both cases, ror mutants significantly differed in the interaction phenotype from $R O R$ genotypes (analysis of variance (ANOVA), tukey test, $P<0.05$ ). The $M L O$ versus $m l o 5$ background genotype apparently did not influence the penetration success.

Transient transformation assay. Both the powdery mildew fungus $B$. graminis f. sp. hordei and $P$. pachyrhizi form appressoria and directly penetrate epidermal cells through the periclinal cell wall. For the interaction of cereals with formae speciales of $B$. graminis transient transformation systems for gene function assessment are well established $(26,42,47)$. We used the available transient microprojectile-mediated transformation protocols to study the nonhost interaction of barley and P. pachyrhizi. As a marker for single cell transformation, we used expression of the green fluorescent protein (GFP) from the Cauliflower mosaic virus $35 \mathrm{~S}$ promoter $(35 S)$. Because penetration by $P$. pachyrhizi leads to death of the epidermal cells, we observed a significant reduction of transformed epidermal cells being attacked by $P$. pachyrhizi and expressing GFP from $24 \mathrm{~h}$ onward. Consequently, the early time point of about $18 \mathrm{hpi}$ turned out to be optimal for the microscopic inspection of fungal penetration success on GFPexpressing cells. Penetration hyphae in the invaded epidermal barley cells, were visible in the transformed epidermal cell, by GFP surrounding fungal structures (Fig. 3A). Thus, transiently transformed epidermis cells were inspected at 16 to 20 hpi with $P$. pachyrhizi.

Because invasion of barley epidermal cells by $P$. pachyrhizi provokes cell death, we wondered if the cell death suppressor BI1 is able to influence interaction with $P$. pachyrhizi. Therefore, we transiently co-expressed GFP and barley $B I-1$ from $35 S$ in epidermal barley cells, which were subsequently inoculated with $P$. pachyrhizi.

In controls co-bombarded with the GFP-construct and an empty $35 S$ vector, $P$. pachyrhizi penetrated $53 \%$ of GFP-expressing cells. Transient over expression of BI-1 led to significantly reduced penetration success of $P$. pachyrhizi. Average fungal success was $38 \%$ corresponding to a relative reduction of penetration rate by $28 \%$ (Fig. 3B). Reduction of penetration efficiency by BI-1 was significant at $P<0.05$ (Student's $t$ test). Data suggest that overexpression of BI-1 supported resistance of barley epidermal cells to penetration by P. pachyrhizi.

Stable transgenic 35S::GFP-BI-1 barley show enhanced resistance to penetration by $P$. pachyrhizi. To further investigate the effect of BI-1 and to characterize the resistance reaction on the single cell level, stable transgenic barley plants bearing a $35 S$ ::GFP-BI-1 construct (13) were inoculated with $P$. pachyrhizi. 
The inoculated leaves were stained with Uvitex2B and aniline blue and displayed either accumulation of callose in CWAs or at the walls of dead cells. The latter was reminiscent of a hypersensitive reaction but was mostly observed in penetrated epidermal cells. The fungus was not regularly stopped by cell death, penetration hyphae transversed the dead cell and the fungus continued growth into the mesophyll. In contrast, callosic CWAs were usually not penetrated by $P$. pachyrhizi and corresponding cells apparently survived.

Over expression of GFP-BI-1 reduced the frequency of epidermal cell death, and cells responded instead with formation of nonpenetrated CWAs. This effect was observed in three independent transgenic $35 S:: G F P-B I-1$ lines (Fig. 4). In contrast, azygous siblings, which had lost the transgene due to segregation and were identified by a lack of amplicon in a polymerase chain reaction (PCR) of the transgene, interacted like the wild type cv. Golden Promise. Compared with wild type plants (WT) and azygous controls, GFP-BI-1 barley reacted significantly different to $P$. pachyrhizi (ANOVA, tukey test, $P<0.05$ ). The formation of CWAs became the predominant defense reaction in GFP-BI-1 plants, which more efficiently prevented penetration by $P$. pachyrhizi when compared to the WT controls. According to these data, cell death might be not effective in restriction of $P$. pachyrhizi on barley but rather promotes penetration of $P$. pachyrhizi.

\section{DISCUSSION}

We characterized the nonhost interaction of barley and $P$. pachyrhizi. Similar to soybean, barley is penetrated by $P$. pachyrhizi, which is accompanied by an epidermal cell death. Epidermal cell death does not generally stop the fungus from penetrating into the mesophyll. Formation of CWAs accompanies penetration resistance at the single cell level, which requires intact $R O R$ genes. Mutation of $R O R 1$ or $R O R 2$ supports penetration and epidermal cell death. In contrast, penetration resistance can be supported by suppression of epidermal cell death by BI-1 suggesting a crucial role of cell death for the penetration success of $P$. pachyrhizi.

The basidiomycete $P$. pachyrhizi forms functional appressoria on barley within 10 hpi and can directly penetrate epidermal cells. However, many penetration attempts of the fungus stop in callosic CWAs. The prevention of penetration by $P$. pachyrhizi was recently reported for the nonhost plant Arabidopsis (38) and was observed for barley in this study. Formation of CWAs and penetration resistance is involved in barley interaction with hemibiotrophic fungi such as M. oryzae (29) or Cochliobolus sativus (35) and with nonadapted biotrophic fungi such as B. graminis f. sp. tritici (54). Race nonspecific powdery mildew resistance of barley plants with mutations in the susceptibility factor $M L O$ also

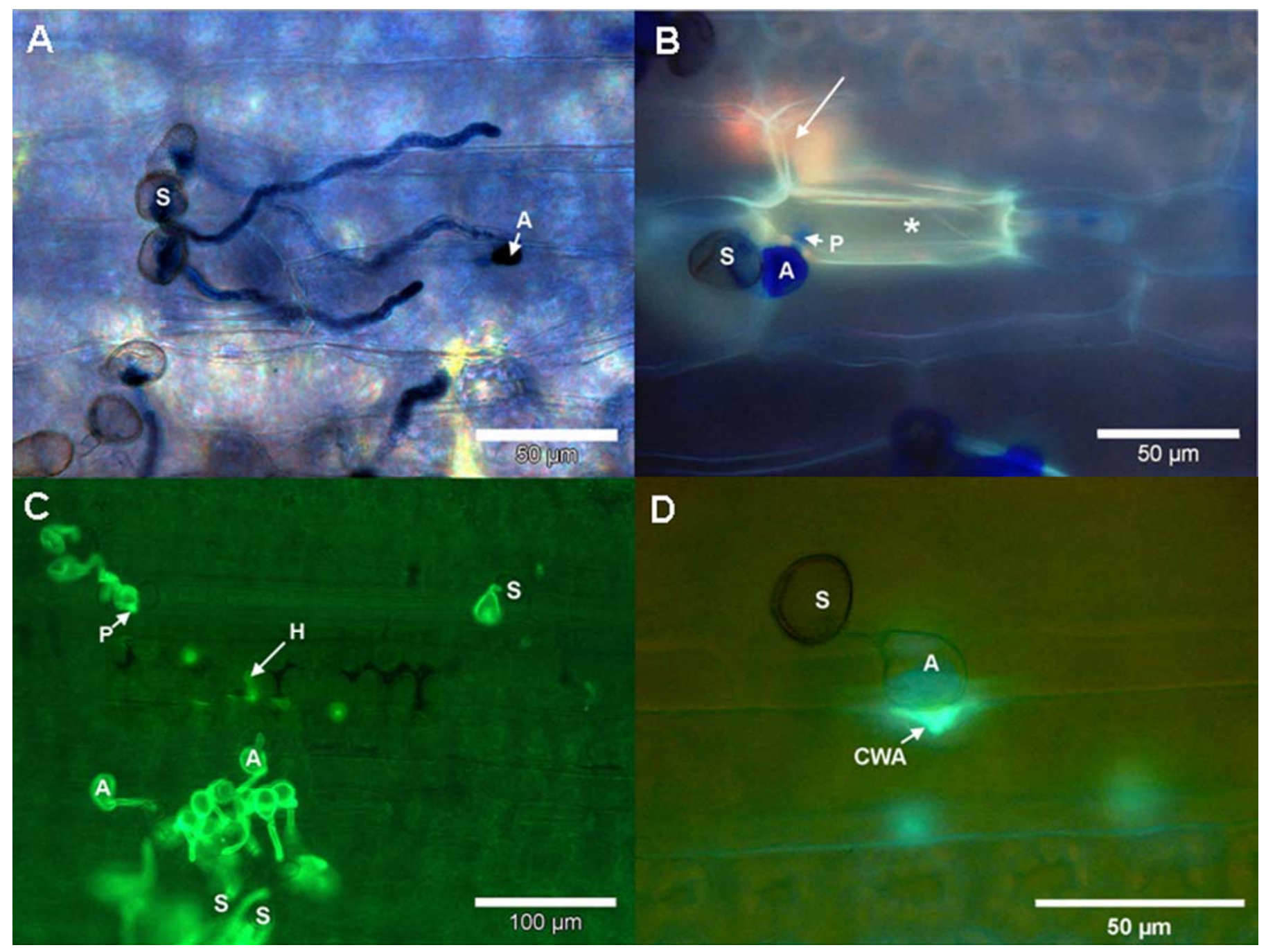

Fig. 1. Microscopy of barley leaves inoculated with Phakopsora pachyrhizi. A, Appressorium, CWA, cell wall apposition, H, invasive hyphae, P, penetration hyphae, S, spore. A, Germination and delayed development of appressoria on barley $6 \mathrm{~h}$ postinoculation stained with Coomassie blue. B, A penetrated epidermal cell (*) shows accumulation of callose (stained with aniline blue) at the cell walls. Autofluorescence in the mesophyll is indicated by the long arrow. C, Fungal hyphae are present between mesophyll cells as evident from cell wall staining with wheat germ agglutin-Alexa488. Overlay of two opical sections. D, Penetration attempt stopped in a callosic CWA. 
results in the formation of nonpenetrated CWAs $(12,17)$. Even in the compatible interaction of barley with $B$. graminis $\mathrm{f}$. sp. hordei only a portion of the germinated spores establish a haustorium and proliferate on the plant. Unsuccessful penetration attempts mostly get arrested in CWAs $(25,61)$. Hence, formation of nonpenetrated CWAs constitutes an overlap of host and nonhost resistance of barley to different fungal pathogens. However, it is still unclear whether the robustness of the CWA itself or accompanying defense reactions such as secretion of antifungal compounds or disarming of fungal pathogenicity factors hinder directly penetrating fungi from entry.

Barley ROR1 and ROR2 genes are required for penetration resistance in interaction with virulent $B$. graminis f. sp. hordei and with nonadapted $B$. graminis f. sp. tritici $(12,17,43,54)$. The nature of ROR1 is unknown but ROR2 codes for a plasma membrane syntaxin that appears involved in focal secretion for penetration defense (12). The Arabidopsis ROR2-ortholog PEN1 is required for full penetration resistance to $B$. graminis $\mathrm{f}$. $\mathrm{sp}$. hordei, and the syntaxin protein focally accumulates at the site of fungal attack $(2,6,12,36)$. However, PEN1 is involved in but not required for Arabidopsis nonhost resistance to Colletotrichum truncatum (48). Furthermore, RORl but not ROR2 is required for basal penetration resistance to $M$. oryzae (29). Hence there are overlapping and distinct functions of ROR1 and ROR2 in resistance to diverse fungal pathogens. Interestingly, ROR 1 and $R O R 2$ are required for nonhost penetration resistance to $P$. pachyrhizi (Fig. 2) but not for basal resistance to the stomata penetrating barley leaf rust fungus Puccinia hordei (11). Additionally, Arabidopsis PEN1 is involved in Arabidopsis penetration resistance to $P$. pachyrhizi (38). Together these data suggest an evolutionary conserved mechanistic similarity of penetration resistance to $B$. graminis and to $P$. pachyrhizi.

Transient over expression of the cell death inhibitor BI-1 in epidermal barley cells significantly reduced the penetration success of $P$. pachyrhizi (Fig. 3). Together with the data from transgenic barley plants expressing GFP-BI-1 (Fig. 4), this shows

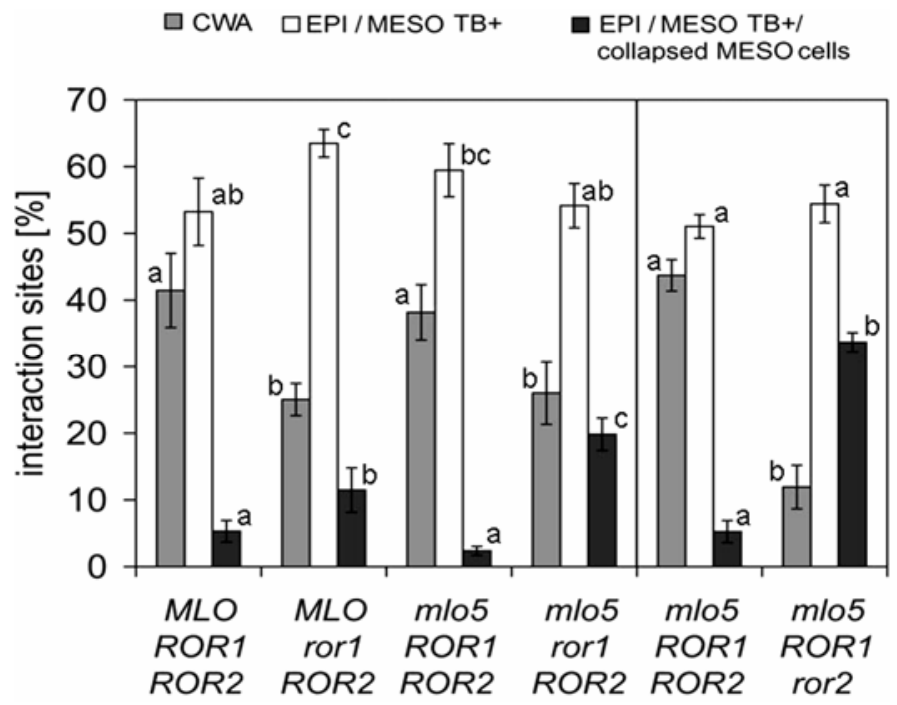

Fig. 2. Penetration resistance of barley ror genotypes to Phakopsora pach$y r h i z i$. Different barley genotypes indicated at the $\mathrm{x}$-axis were inoculated and microscopically evaluated at two or four (mlo5 ROR1 ROR2 versus mlo5 ROR1 ror2) days after inoculation. Interaction sites were categorized in those with fungal appressoria, which did not successfully penetrate a cell wall apposition (CWA), fungal attacks, which provoked tryphan blue positive reactions in the epidermis and the mesophyll (EPI/MESO TB+) and fungal attacks, which provoked tryphan blue positive reactions together with mesophyll cell collapse (EPI/MESO TB+/collapsed MESO cells). Error bars represent $95 \%$ confidence intervals of the samples. For each category, columns labeled with the same letter are not significantly different at $P<0.05$ according to analysis of variance followed by a tukey test. that microprojectile-mediated transformation is a suitable tool to assess gene functions not only in interaction with $B$. graminis $(42,47)$ but also in interaction with $P$. pachyrhizi. A closer inspection of the interaction at the level of the first attacked cell in stable transgenic barley plants over expressing GFP-BI-1 revealed a reduced rate of cell death accompanied with a higher rate of CWA formation in attacked epidermal cells. Hence, the inhibition of $P$. pachyrhizi-triggered cell death by GFP-BI-1 seems to promote resistance to fungal entry. The rust fungus Uromyces vignae, which is adapted on cowpea, also directly penetrates the epidermal cell wall in its monokaryotic stage (basidiospore) (21). In the nonhost interaction of $U$. vignae and pea, cell wall associated defense reactions predominate and prevent fungal penetration. The predominant defense reaction in resistant cowpea host plants to uredospores of $U$. vignae is an HR of penetrated cells, which is triggered by fungal avirulence gene products and stops fungal development. In contrast, penetration failure of $U$. vignae on susceptible cowpea is rare, and penetrated cells survive in a compatible interaction (21). On both nonhost barley (Fig. 1) and host soybean (32), P. pachyrhizi triggers cell death of penetrated
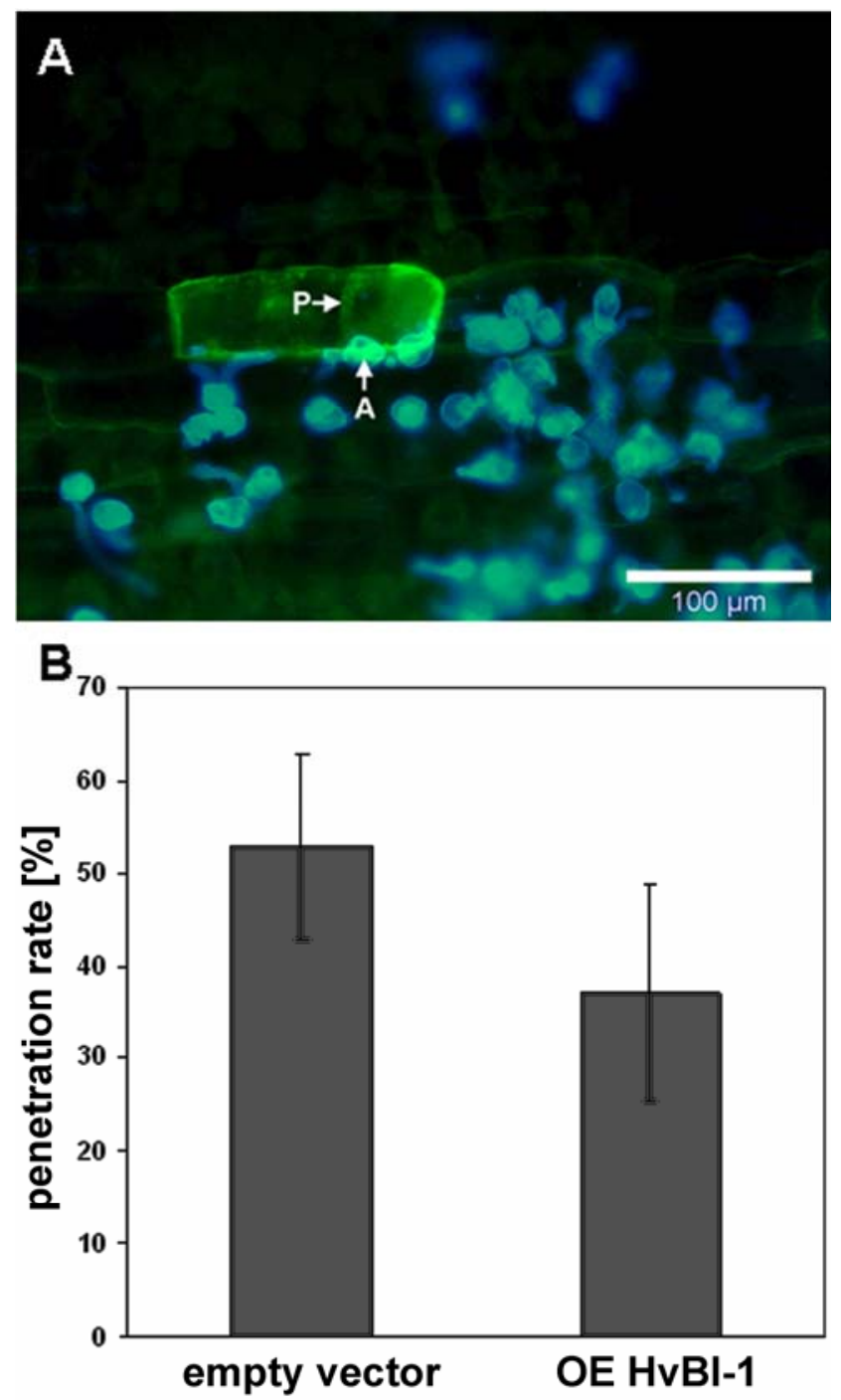

Fig. 3. Transient over expression of barley BI-1 limits penetration success of Phakopsora pachyrhizi. A, Epidermal barley cell transiently transformed with a green fluorescent protein (GFP)-reporter construct penetrated by $P$. pachyrhizi. The penetration hypha is indicated by an arrowhead. A, appressorium, $\mathrm{P}$, penetration hyphae. B, Penetration rate of $P$. pachyrhizi in transiently BI-1 over expressing barley epidermal cells was reduced compared to empty vector controls. Columns represent the average of three independent experiments. Error bars represent $95 \%$ confidence intervals of the samples. 
epidermal cells, which does not stop fungal development but is followed by spread of fungal hyphae into the mesophyll. Hence, in contrast to basidiospores of $U$. vignae, uredospores of $P$. pachyrhizi do not operate like a true biotroph during penetration of the epidermal layer. As observed in barley and in Arabidopsis (38), P. pachyrhizi can transverse dead epidermal cells and continues growth in the mesophyll. We speculate that epidermal cell death could be induced by the fungus to avoid plant defense reactions. As proposed by Loehrer et al. (38), P. pachyrhizi shows some features in the initial steps of infection that are typical for necrotrophs. A dead cell may no longer be able to prevent fungal development and may facilitate fungal passage into the intercellular space. If and how the fungus actively induces plant PCD is unknown. However, the fact that over expression of BI-1 restricted fungal development on barley, suggests that cell death could play a role in early invasive growth of $P$. pachyrhizi.

Although the fungus invaded the mesophyll of barley, no haustoria were apparent and no sporulation appeared. Instead mesophyll cell death occurred. This is reminiscent of a typical nonhost resistance reaction to penetration by biotrophic haustoria forming fungi $(11,20,54)$ and supports that $P$. pachyrhizi, once it has reached the mesophyll layer, switches to a biotrophic life style as typical for rust fungi.

$B I-1$ gene expression is activated or suppressed in several reactions of plants to the biotic environment $(13,15,26,27,41,45,59)$. Recently, two soybean BI-1 like proteins have been identified in a screen for differentially expressed genes in the soybean genotype RPPl during comparison of incompatible versus compatible interaction with different isolates of $P$. pachyrhizi. Both genes were found in a cluster of 53 genes that show a typical expression profile of early up-regulation (6 to $12 \mathrm{hpi}$ ) and subsequent downregulation (24 to $48 \mathrm{hpi}$ ) during the race-specific resistance response (8). This indicates a potential role of soybean BI-1 in natural resistance to $P$. pachyrhizi.

Provocation of cell death by rust fungi appears unusual but is observed in the infection process of necrotrophic fungi such as $B$. cinerea (9) and Fusarium moniliforme $(1,52)$ and is induced by elicitors derived from M. oryzae (41). However, M. oryzae elicitor treated transgenic rice cells over expressing Arabidopsis BI-1 showed sustainable cell survival (41). F. moniliforme produces the PCD inducing toxin fumonisin B1 $(1,52)$, and fumonisin B1-

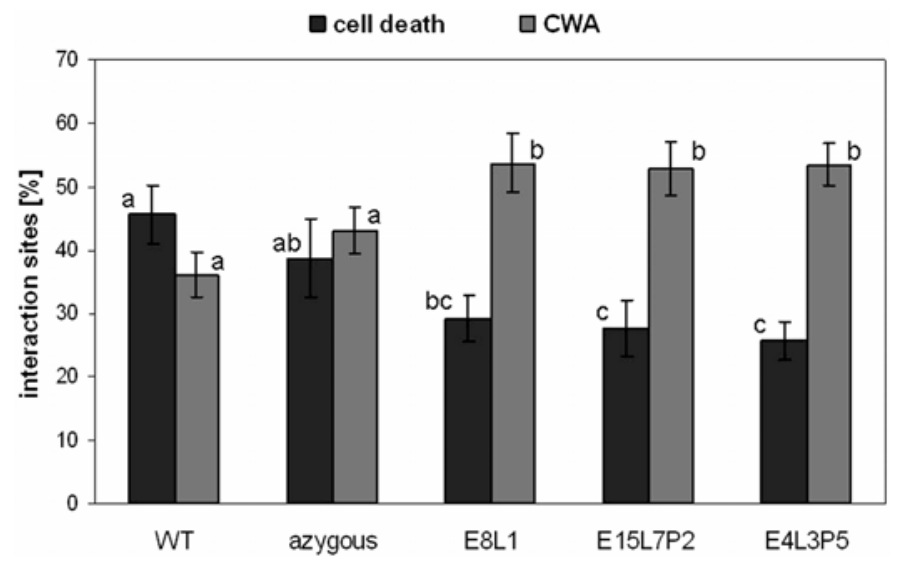

Fig. 4. Microscopic inspection of the interaction phenotype of green fluorescent protein (GFP)-BI-1 barley. GFP-BI-1 over expressing barley lines E8L1, E15L7 and E4L3 displayed enhanced formation of nonpenetrated cell wall appositions (CWAs) in cells attacked by Phakopsora pachyrhizi. Accordingly, cell death induced by $P$. pachyrhizi was reduced in these plants. WT, wild type. Columns represent the average of three independent experiments. Error bars represent $95 \%$ confidence intervals of the samples. Rare events of barley cells showing no reaction upon pathogen attack are not included in the figure. For each category, columns labeled with the same letter are not significantly different at $P<0.05$ according to analysis of variance followed by a tukey test. induced cell death is accelerated in Arabidopsis bi-1 mutants (56). In contrast, over expression of barley BI-1 protects carrots from leaf necrosis induced by $B$. cinerea (28). Additionally, the rootcolonizing mutualistic fungus Piriformospora indica, which proliferates in dead barley cells, is partially restricted in $35 S:: G F P$ $B I-1$ barley (13). The same $35 S:: G F P-B I-1$ barley plants were more resistant to root rot provoked by Fusarium graminearum (3) and to penetration by $P$. pachyrhizi. Thus, BI-1-mediated cell survival may allow for activation of cell death-independent defense at the plant cell wall. Astonishingly, BI-1 greatly weakens barley host and nonhost penetration resistance to biotrophic $B$. graminis $(3,14,15,26)$ but supports penetration resistance to $P$. pachyrhizi. This points to a complex signaling network including crosstalk between cell death regulation and cell wall associated plant defense.

\section{ACKNOWLEDGMENTS}

We thank R. Proels for critical reading of the manuscript and K. Staiger for skillful technical assistance. We are grateful to M. Hess for supporting the statistical analysis. This work was supported by a grant from the German research foundation to R. Huckelhoven (DFG HU886/1)

\section{LITERATURE CITED}

1. Asai, T., Stone, J. M., Heard, J. E., Kovtun, Y., Yorgey, P., Sheen, J., and Ausubel, F. M. 2000. Fumonisin B1-induced cell death in Arabidopsis protoplasts requires jasmonate-, ethylene-, and salicylate-dependent signaling pathways. Plant Cell 12:1823-1836.

2. Assaad, F. F., Qiu, J. L., Youngs, H., Ehrhardt, D., Zimmerli, L., Kalde, M., Wanner, G., Peck, S. C., Edwards, H., Ramonell, K., Somerville, C. R. and Thordal-Christensen, H. 2004. The PEN1 syntaxin defines a novel cellular compartment upon fungal attack and is required for the timely assembly of papillae. Mol. Biol. Cell 15:5118-5129.

3. Babaeizad, V., Imani, J., Kogel, K.-H., Eichmann, R., and Hückelhoven, R. 2008. Over-expression of the cell death regulator BAX inhibitor-1 in barley confers reduced or enhanced susceptibility to distinct fungal pathogens. Theor. Appl. Genet. Doi:10.1007/s00122-008-0912-2.

4. Baek, D., Nam, J., Koo, Y. D., Kim, D. H., Lee, J., Jeong, J. C., Kwak, S.S., Chung, W. S., Lim, C. O., Bahk, J. D. , Hong, J. C., Lee, S. Y., KawaiYamada, M., Uchiyama, H., and Yun, D.-J. 2004. Bax-induced cell death of Arabidopsis is mediated through reactive oxygen-dependent and independent processes. Plant Mol. Biol. 56:15-27.

5. Beers, E. P., and McDowell, J. M. 2001. Regulation and execution of programmed cell death in response to pathogens, stress and developmental cues. Curr. Opin. Plant Biol. 4:561-567.

6. Bhat, R. A., Miklis, M., Schmelzer, E., Schulze-Lefert, P., and Panstruga, R. 2005. Recruitment and interaction dynamics of plant penetration resistance components in a plasma membrane microdomain. Proc. Natl. Acad. Sci. USA 102:3135-3140.

7. Chisholm, S. T., Coaker, G., Day, B., and Staskawicz, B. J. 2006. Hostmicrobe interactions: Shaping the evolution of the plant immune response. Cell 24:803-814.

8. Choi, J. J., Alkharouf, N. W., Schneider, K. T., Matthews, B. F., and Frederick, R. D. 2008. Expression patterns in soybean resistant to Phakopsora pachyrhizi reveal the importance of peroxidases and lipoxygenases. Funct. Integr. Genomics 8:341-359.

9. Choquer, M., Fournier, E., Kunz, C., Levis, C., Pradier, J.-M., Simon, A., and Viaud, M. 2007. Botrytis cinerea virulence factors: New insights into a necrotrophic and polyphageous pathogen. FEMS Microbiol. Lett. 277:1-10.

10. Collins, N. C., Lahaye, T., Peterhänsel, C., Freialdenhoven, A., Corbitt, M., and Schulze-Lefert, P. 2001. Sequence haplotypes revealed by sequence-tagged site fine mapping of the Rorl gene in the centromeric region of barley chromosome 1H. Plant Physiol. 125:1236-1247.

11. Collins N. C., Niks, R. E., and Schulze-Lefert, P. 2007. Resistance to cereal rusts at the plant cell wall-what can we learn from other hostpathogen systems? Aust. J. Agric. Res. 58:476-489.

12. Collins N. C., Thordal-Christensen, H., Lipka, V., Bau, S., Kombrink, E., Qiu, J. L., Hückelhoven, R., Stein, M., Freialdenhoven, A., Somerville, S. C., and Schulze-Lefert, P. 2003. SNARE-protein-mediated disease resistance at the plant cell wall. Nature 425:973-977.

13. Deshmukh, S., Hückelhoven, R., Schäfer, P., Imani, J., Sharma, M., Weiss, M., Waller, F., and Kogel, K. H. 2006. The root endophytic fungus Piriformospora indica requires host cell death for proliferation during 
mutualistic symbiosis with barley. Proc. Natl. Acad. Sci. USA 103:1845018457.

14. Eichmann, R., Dechert, C., Kogel, K.-H., and Hückelhoven, R. 2006. Transient over-expression of barley BAX Inhibitor-1 weakens oxidative defence and MLA12-mediated resistance to Blumeria graminis f. sp. hordei. Mol. Plant Pathol. 7:543-552.

15. Eichmann, R., Schultheiss, H., Kogel, K. H., and Hückelhoven, R. 2004. The barley apoptosis suppressor homologue BAX inhibitor-1 compromises nonhost penetration resistance of barley to the inappropriate pathogen Blumeria graminis f. sp. tritici. Mol. Plant-Microbe Interact. 17:484-490.

16. Frederick, R. D., Snyder, C. L., Peterson, G. L., and Bonde, M. R. 2002. Polymerase chain reaction assays for the detection and discrimination of the soybean rust pathogens Phakopsora pachyrhizi and P. meibomiae. Phytopathology 92:217-227.

17. Freialdenhoven, A., Peterhänsel, C., Kurth, J., Kreuzaler, F., and SchulzeLefert, P. 1996. Identification of genes required for the function of nonrace-specific mlo resistance to powdery mildew in barley. Plant Cell 8:514.

18. Green, D. R., and Reed, J. C. 1998. Mitochondria and apoptosis. Science 281:1309-1312.

19. Greenberg, J. T., and Yao, N. 2004. The role and regulation of programmed cell death in plan-pathogen interactions. Cell Microbiol. 6:201-211.

20. Heath, M. 2000. Hypersensitive response-related death. Plant Mol. Biol. 44:321-334.

21. Heath, M. C. 2002. Cellular interactions between biotrophic fungal pathogens and host or nonhost plants. Can. J. Plant Pathol. 24:259-264.

22. Hoch, H. C., Staples, R. C., Whitehead, B., Comeau J., and Wolf, E. D. 1987. Signaling for growth orientation and cell differentiation by surface topography in Uromyces. Science 235:1659-1662.

23. Hoppe, H. H., and Koch, E. 1986. Expression of host and non-host resistance against two races of the soybean rust fungus. Proceedings of the International Congress of SABRAO (Bangkok 1985):833-840.

24. Hückelhoven, R. 2004. BAX Inhibitor-1, an ancient cell death suppressor in animals and plants with prokaryotic relatives. Apoptosis 9:299-307.

25. Hückelhoven, R. 2007. Cell wall-associated mechanisms of disease resistance and susceptibility. Annu. Rev. Phytopathol. 45:101-127.

26. Hückelhoven, R., Dechert, C., and Kogel, K. H. 2003. Over expression of barley BAX inhibitor 1 induces breakdown of mlo-mediated penetration resistance to Blumeria graminis. Proc. Natl. Acad. Sci. USA 29:55555560 .

27. Hückelhoven, R., Dechert, C., Trujillo, M., and Kogel, K.-H. 2001. Differential expression of putative cell death regulator genes in nearisogenic, resistant and susceptible barley lines inoculated with the powdery mildew fungus. Plant Mol. Biol. 47:739-748.

28. Imani, J., Baltruschat, H., Stein, E., Gengxiang, J., Vogelsberg, J., Kogel, K., and Hückelhoven, R. 2006. Expression of barley Bax inhibitor-1 in carrots confers resistance to Botrytis cinerea. Mol. Plant Pathol. 7:279284.

29. Jarosch, B., Collins, N. C., Zellerhof, N., and Schaffrath, U. 2005. RAR1, $R O R 1$, and the actin cytoskeleton contribute to the basal resistance to Magnaporthe grisea. Mol. Plant-Microbe Interact. 18:397-404.

30. Jones, D. A., and Takemoto, D. 2004. Plant innate immunity - direct and indirect recognition of general and specific pathogen-associated molecules. Curr. Opin. Immunol. 16:48-62.

31. Keogh, R. C., Deverall, B. J., and Mcleod, S. 1980. Comparison of histological and physiological responses to Phakopsora pachyrhizi in resistant and susceptible soybean. Trans. Br. Mycol. Sci. 74:329-333.

32. Koch, E., Ebrahim-Nesbat F., and Hoppe, H. H. 1983. Light and electron microscopic studies on the development of soybean rust Phakopsora pachyrhizi in susceptible soybean leaves. J. Phytopathol. 106:302-320.

33. Koch, E. and Hoppe, H. H. 1988. Development of infection structures by the direct penetrating soybean rust fungus Phakopsora pachyrhizi on artificial membranes. J. Phytopathol. 122:232-244.

34. Koonin, E. V., and Aravind, L. 2002. Origin and evolution of eukaryotic apoptosis: The bacterial connection. Cell Death Differ. 9:394-404.

35. Kumar, J., Schäfer, P., Hückelhoven, R., Langen, G., Baltruschat, H., Stein, E., Nagarajan, S., and Kogel, K.-H. 2002. Bipolaris sorokiniana, a cereal pathogen of global concern: Cytological and molecular approaches towards better control. Mol. Plant Pathol. 3:185-195.

36. Kwon, C., Neu, C., Pajonk, S., Yun, H. S., Lipka, U., Humphry, M., Bau S., Straus, M., Kwaaitaal, M., Rampelt, H., El Kasmi, F., Jürgens, G., Parker, J., Panstruga, R., Lipka, V., and Schulze-Lefert, P. 2008. Cooption of a default secretory pathway for plant immune responses. Nature 451:835-840.

37. Lacomme, C., and Santa Cruz, S. 1999. Bax-induced cell death in tobacco is similar to the hypersensitive response. Proc. Nat. Acad. Sci. USA 96:7956-7961.
38. Loehrer, M., Langenbach, C., Goellner, K., Conrath, U., and Schaffrath, U. 2008. Characterization of nonhost resistance of Arabidopsis to the Asian Soybean Rust. Mol. Plant-Microbe Interact. 21:1421-1430.

39. Ma, W., and Berkowitz, G. A. 2007. The grateful dead: Calcium and cell death in plant innate immunity. Cell. Microbiol. 9:2571-2585.

40. Madeo, F., Herker, E., Wissing, S., Jungwirth, H., Eisenberg, T., and Fröhlich, K. U. 2004. Apoptosis in yeast. Curr. Opin. Microbiol. 7:655660.

41. Matsumura, H., Nirasawa, S., Kiba, A., Urasaki, N., Saitoh, H., Ito, M., Kawai-Yamada, M., Uchimiya, H., and Terauchi, R. 2003. Overexpression of Bax inhibitor suppresses the fungal elicitor-induced cell death in rice (Oryza sativa L.) cells. Plant J. 33:425-434.

42. Nielsen, K., Olsen, O., and Oliver, R. 1999. A transient expression system to assay putative antifungal genes on powdery mildew infected barley leaves. Physiol. Mol. Plant P. 54:1-12.

43. Peterhänsel, C., Freialdenhoven, A., Kurth, J., Kolsch, R., and SchulzeLefert, P. 1997. Interaction analyses of genes required for resistance responses to powdery mildew in barley reveal distinct pathways leading to leaf cell death. Plant Cell 9:1397-1409.

44. Read, N. D., Kellock, L. J., Collins, T. J., and Gundlach, A. M. 1997. Role of topography sensing for infection-structure differentiation in cereal rust fungi. Planta 202:163-170.

45. Sanchez, P., de Torres Zabala, M., and Grant, M. 2000. AtBI-1, a plant homologue of Bax inhibitor-1, suppresses Bax-induced cell death in yeast and is rapidly upregulated during wounding and pathogen challenge. Plant J. 21:393-399.

46. Schmelzer, E. 2002. Cell polarization, a crucial process in fungal defence. Trend Plant Sci. 7:411-415.

47. Schweizer, P., Pokorny, J., Abderhalden, O., and Dudler, R. 1999. A transient assay system for the functional assessment of defense-related genes in wheat. Mol. Plant-Microbe Interact. 12:647-654.

48. Shimada, C., Lipka, V., O'Connell, R., Okuno, T., Schulze-Lefert, P., and Takano, Y. 2006. Nonhost resistance in Arabidopsis-Colletotrichum interactions acts at the cell periphery and requires actin filament function. Mol. Plant-Microbe Interact. 19:270-279.

49. Shirasu, K., Lahaye, T., Tan, M. W., Zhou, F., Azevedo, C., and SchulzeLefert, P. 1999. A novel class of eukaryotic zinc-binding proteins is required for disease resistance signaling in barley and development in $C$. elegans. Cell 99:355-366.

50. Silva, D. G., Yamanaka, N., Brogin, R. L., Arias, C. A. A., Nepomuceno, A. L., Di Mauro, A. O., Pereira, S. S., Nogueira, L. N., Passianotto, A. L. L., and Abdelnoor, R. V. 2008. Molecular mapping of two loci that confer resistance to Asian rust in soybean. Theor. Appl. Genet. DOI:10.1007/ s00122-008-0752-0.

51. Slaminko, T. L., Miles, M. R., Frederick, R. D., Bonde, M. R., and Hartman, G. L. 2008. New legume hosts of Phakopsora pachyrhizi based on greenhouse evaluations. Plant Dis. 92:767-771.

52. Stone, J. M., Heard, J. E., Asai, T., and Ausubel, F. M. 2000. Simulation of fungal-mediated cell death by fumonisin B1 and selection of fumonisin B1-resistant (fbr) Arabidopsis mutants. Plant Cell 12:1811-1822.

53. Thordal-Christensen, H. 2003. Fresh insights into processes of nonhost resistance. Curr. Opin. Plant Biol. 6:351-357.

54. Trujillo, M., Troeger, M., Niks, R., Kogel, K.-H., and Hückelhoven, R. 2004 Mechanistic and genetic overlap of barley host and non-host resistance to Blumeria graminis. Mol. Plant Pathol. 5:389-396.

55. von Röpenack, E., Parr, A., and Schulze-Lefert, P. 1998. Structural analyses and dynamics of soluble and cell wall-bound phenolics in a broad spectrum resistance to the powdery mildew fungus in barley. J. Biol. Chem. 273:9013-9022.

56. Watanabe, N., and Lam, E. 2006. Arabidopsis Bax inhibitor-1 functions as an attenuator of biotic and abiotic types of cell death. Plant J. 45:884894.

57. Xu, H., and Heath, M. C. 1998. Role of calcium in signal transduction during the hypersensitive response caused by basidiospore-derived infection of the cowpea rust fungus. Plant Cell 10:585-598.

58. Xu, Q., and Reed, J. C. 1998. Bax inhibitor-1, a mammalian apoptosis suppressor identified by functional screening in yeast. Mol. Cell 1:337346.

59. Xu, P., Blancaflor, E. B., and Roossinck, M. J. 2003. In spite of induced multiple defense responses, tomato plants infected with Cucumber mosaic virus and D satellite RNA succumb to systemic necrosis. Mol. PlantMicrobe Interact. 16:467-476.

60. Yeh, C. C., Tschanz, A. T., and Sinclair, J. B. 1981. Induced teliospore formation by Phakopsora pachyrhizi on soybeans and other hosts. Phytopathology 71:1111-1112.

61. Zeyen, R. J., Carver, T. L. W., and Lyngkjaer, M. F. 2002. Epidermal cell papillae. Pages 107-124 in: The Powdery Mildews. R. R. Bélanger, W. R. Bushnell, A. J. Dik, and T. L. W. Carver, eds. American Phytopathological Society, St. Paul, MN. 